\title{
Strategic Price Positioning for Revenue Management: The Effects of Relative Price Position and Fluctuation on Performance
}

\author{
Breffni M. Noone, Pennsylvania University \\ Linda Canina, Cornell University \\ Cathy A. Enz, Cornell University
}

\begin{abstract}
Emerging price optimization models systematically incorporate competitor price information into the derivation of optimal price points. While consideration of competitor pricing at this tactical level is essential to maximizing short-term revenues, the long-term impact of competitive price positioning on revenue performance should not be overlooked. This study examines the effect of two key dimensions of strategic price positioning - relative price position and relative price fluctuation - on the revenue performance of 6998 US hotels over an 11-year period. It finds that revenue performance is strongest for hotels that price higher than the competition and maintain a consistent relative price over time. Implications for revenue management practitioners are discussed.
\end{abstract}

\section{Introduction}

Firms are typically very sensitive to the activities of their competitors (Lambin et al, 1975; Hanssens, 1980). Pricing decisions in particular tend to elicit firms' responses more than other types of competitor activities and play a key role in shaping the market share of a firm (Hanssens, 1980; Ailawadi et al, 2001). In their examination of retail pricing, Shankar and Bolton (2004) found, for example, that competitor price levels and competitor deal frequency were the most dominant determinants of retailer pricing, demonstrating the power of competitor pricing to shape key organizational decisions. Recognizing the impact of competitor pricing on demand and associated revenues, the focus of revenue management $(\mathrm{RM})$ is shifting from inventory optimization (that is, what is the right amount of inventory to sell at a given price?) to price optimization (that is, what is the right price in the first place?).

Emerging price optimization models systematically incorporate competitor prices, in addition to demand elasticities and forecasted demand, to establish the optimal prices in order to maximize revenue (Cross et al, 2009). These emerging models are designed to support tactical pricing decisions, 
but the pricing recommendations that they yield should be consistent with the firm's overarching strategic price positioning (Lieberman, 2004). In other words, tactical pricing optimizes price to take into account short-term market dynamics including demand shifts and competitor pricing, which may result in short-term changes in price positioning vis a vis competitors. However, these decisions should largely support the firm's desired long-term price position. A firm's strategic price position reflects where it positions itself in the long-term relative to the competition. Price position (that is, relative price higher or lower than, or on par with, the competition) and relative price fluctuation (that is, the degree of variation in price relative to the competition) over time have been identified in the literature as two key dimensions of strategic pricing (Bolton and Shankar, 2003). In their examination of grocery retailer pricing strategies, Bolton and Shankar (2003) found support for considerable variability in retailer's positions on these two pricing dimensions. However, they did not examine the performance effects (for example, revenue or profit implications) of alternative positions along the two dimensions.

In this article we seek to extend the literature by examining how relative price position and relative price fluctuation shape long-term performance. Because the RM literature has focused primarily on the application of competitor price information to support tactical pricing decisions, it provides little insight into the effectiveness of long-term price positioning strategies. Thus, in this study we explore the revenue impact of the relative price position and relative price fluctuation dimensions of strategic pricing in a hotel context. Specifically, using average daily rate (ADR) and revenue per available room (RevPAR) data for 6998 US hotels across an 11-year time period (2000 through 2010 inclusive), we test the effects of relative price position and relative price fluctuation on RevPAR performance. We also examine the nature of these relationships by hotel type - luxury, upscale, midscale, economy and budget - to determine if the results obtained across all properties in the industry can be extrapolated to sub-segments of the industry. It should be noted that this study does not seek to make any inferences regarding how hotels reached their relative price positions, whether it was the outcome of good (or bad) management of relative price across market segments (for example, transient versus group) and/or distribution channels (for example, hotel direct versus third-party distribution channels). Rather, the focus is on how the strategic relative price position achieved by hotels impacts long-term RevPAR performance. 


\section{Background Literature}

\section{From Inventory Optimization to Price Optimization}

Standard, quantity-based RM practice separates pricing and capacity allocation decisions (Gallego and Hu, 2007). Revenue managers have traditionally been charged with the task of allocating available capacity given a predefined rate structure, with no consideration of the pricing and quality attributes of the products available to consumers at the time of purchase. Legacy RM systems have been designed under the assumption that demands for different rate classes are independent random variables (see, for example, Talluri and van Ryzin, 2004). However, the reality is that demand for a given firm's product at a given price is impacted by the availability of lower prices, both those offered by the firm (for the same product) and those for comparable competitors' products. These data are easily obtained by the consumer via the Internet during the purchase process.

Recognizing the impact that competitors' prices can have on demand and associated revenues, recent RM research and practice has sought to address the shortcomings of traditional RM models through the systematic incorporation of competitor price information. Drawing on the literature in a number of domains including, for example, game theory and the quasi-variational inequalities literature, several approaches to modeling the RM problem under competition have been explored (for example, Perakis and Sood, 2006; Mookherjee and Friesz, 2008; Levin et al, 2009; for an overview see Gallego and $\mathrm{Hu}$, 2007). There is also evidence from the field of a movement towards the incorporation of competitor price into RM systems. This development has been facilitated significantly by the availability of rate shopping tools that automate the collection of competitor price data from across multiple Internetbased distribution channels. Dollar Rent-A-Car was one of the first companies to develop an automated and integrated capability for modifying the price recommendations of its RM system based on competitor prices (Lieberman, 2004). A number of hotel companies have also moved towards the application of price optimization models that use competitor price information, in addition to forecasted demand and the elasticity of demand in the market, to set prices. Research suggests that price optimization will increase transient revenue by 3-4 per cent over and above the revenue gains from traditional RM (Cross et al, 2009). While these incremental revenue results are very attractive, it is imperative that the short-term tactical pricing decisions that emerging price optimization models are designed to support are consistent with the desired overall pricing strategy of the firm. 


\section{Strategic Price Positioning}

A firm should have a clear vision of how it wants to position itself in the long-term vis $a$ vis its competitors, whether communicated in highly objective statements (for example, 'we will always be within $\$ 5$ of brand $X^{\prime}$ ) or more subjective statements (for example, 'we will always be the lowest priced brand in this market'). Once established, these positioning goals, in addition to a number of other goals or constraints (for example, market-share goals, product/service differentiation constraints), should inform the regular pricing tactics adopted by the firm (Hawtin, 2003). In other words, day-to-day pricing decisions should comply with strategic price positioning such that progress is made towards the firm's long-term goals. Lieberman (2004) suggests that incorporating competitor prices into RM models will facilitate RM systems' responsiveness to a firm's strategic price positioning policies. He notes that, when price recommendations lead to potential conflicts between maximizing short-term profits and maintaining consistency with a firm's strategic price positioning, such information can be brought to the attention of appropriate personnel. If such conflicts occur often, and the impacts on profits are sufficiently high, such information might lead a firm to investigate whether changes in its competitive price positioning strategy are warranted.

While the need to closely align tactical pricing decisions with strategic price positioning is clear, the literature provides little guidance in the domain of strategic price positioning. Bolton and Shankar (2003) suggest that relative price position - higher or lower than, or on par with, the competition - and price fluctuation relative to the competition, are two key dimensions of strategic pricing. A number of authors have examined the impact of relative price position on performance (for example, Alam et al, 2001; Enz et al, 2004, 2009; Enz and Canina, 2010). However, the relative price fluctuation-performance relationship has received less attention. Since both dimensions of pricing are integral to an overall competitive positioning strategy, this study explores their joint effects on revenue performance.

\section{Relative Price Position}

A number of previous studies have examined the performance effects of price positioning strategies. For example, Alam et al (2001) investigated the implication of strategic pricing behavior for technical efficiency in the context of the airline industry. ${ }^{1}$ They found evidence of dynamic, route-level, parallel pricing despite highly variable price structures and concluded that, in this context (that is, where firms maintain pricing strategies that are volatile yet similar), airlines may not be attaining maximum technical efficiency. Following their assessment of super deluxe hotels in Seoul, Chung (2000) concluded that a price-cutting strategy (that is, Nash pricing strategy) does not allow hotels to gain greater market 
share, even during off- peak periods. Rather, a monopolistic pricing strategy (that is, price at a level that would maximize the revenues of every hotel: a higher-price strategy), or a revocable pricing strategy (that is, price at a level under the assumption that other hotels will follow that lead: a higher-price strategy), will serve the dual purposes of maintaining the market share of every hotel and increasing total revenue of the market as a whole. In a series of studies that examine the ADR positioning-RevPAR relationship, researchers found, both in the context of the US and European hotel markets, that hotels with an ADR above that of their direct competitors generate higher relative RevPAR (Enz et al, 2004, 2009; Enz and Canina, 2010). In other words, an overall ADR lower than the competitive set may not yield the revenue results typically expected from discounting. In a similar vein, research on the longterm effects of price promotions on consumers' brand choice behavior in the context of packaged goods suggests that such activity may not lead to increases in sales volume. Rather, consumers can become more price and promotion sensitive over time (Mela et al, 1997).

Relative Price Fluctuation

Prior literature suggests that high variability or fluctuation in prices may negatively impact brand evaluations and erode brand equity (for example, Aaker, 1996; Erdem and Swait, 1998). A significant degree of price fluctuation can negatively impact consumers' quality perceptions, with increased uncertainty about brand quality increasing consumers' perceived risk (Swait and Erdem, 2002). While the negative effect of price inconsistency on brand equity can be expected to decrease consumer utility, price fluctuation may also increase utility (Swait and Erdem, 2002). The latter effect may be the result of a 'deal' effect, either as a function of the opportunity of paying a lower price on average, or increased expected transaction utility ${ }^{2}$ (Thaler, 1985), even if consumers do not pay lower prices.

Swait and Erdem (2002) provide evidence of a double effect of price fluctuation on consumer utility. They found, in the context of a frequently purchased consumer good, that price variability tends to increase consumer utility; however, this effect is moderated by price predictability (that is, the degree of regularity and predictability of promotional patterns). Specifically, the net effect of price variability on consumer utility can become negative at high levels of price predictability, and lead to share losses, as a result of lower expected transaction utility.

The potential for a negative price fluctuation-consumer utility relationship raises an obvious concern in the RM arena: will price fluctuation (that is, variability in average price over time) lead to suboptimal revenue performance? While the topic of relative price positioning has received some attention in the RM literature, an understanding of the nature of the relationship between price fluctuation and 
revenue, in addition to an awareness of the revenue impact of relative price position, is essential to the development of an effective strategic price positioning strategy. Thus, this study seeks to complement existing research in the domain of strategic price positioning by examining the joint effects of relative price position, and fluctuation, on revenue performance over time. While prior studies (for example, Swait and Erdem, 2002; Bolton and Shankar, 2003) have examined price fluctuation from the perspective of variability in individual products' prices over time, this study assesses the price fluctuation of individual property's prices relative to their competitive set over time.

\section{Method}

\section{Sample}

The data were obtained from Smith Travel Research (STR), which collects and collates hotel property data for over 98 per cent of the population of branded hotels in the United States. The STR data consisted of monthly hotel-level performance data - room revenue and rooms sold for the period 2000-2010. In addition, STR supplied categorical variables that describe some of the characteristics of each firm. These data included (1) the number of rooms in the hotel, (2) the number of available rooms in the hotel, (3) the regional location of the hotel, (4) the location type of the hotel ${ }^{3}$ and (4) the product/service quality segment category of the hotel. ${ }^{4}$ The unit of analysis was individual hotel properties. Properties with less than 12 months of data in any of the years under review were eliminated from the sample, resulting in a sample size of6998 hotel properties. All hotel types (that is, luxury, upscale, midscale, economy and budget) and locations (that is, urban, suburban, airport, interstate, resort and small town/metro) were represented.

\section{Measures}

Performance: One of the most important performance measures in the lodging industry is RevPAR. This indicator serves as the basis for long-term business planning and is used as a guide by investors, hotel owners and general managers. RevPAR was calculated by dividing total room revenue over the 11-year period by the total number of rooms available for sale over the 11-year period.

Relative price position: Relative price position represents a measure of the mean ADR attained by a given hotel relative to the competitive set, and was computed for each hotel in the sample as the average of the annual ADR percentage difference from the competitive set over the 11-year period. Thus, ADR was computed for each property in the sample and each property's competitive set by year. The ADR was computed for each property and for each property's competitive set by dividing annual 
rooms revenue by annual rooms sold by year. To calculate percentage difference in ADR, the annual ADR of a competitive set was subtracted from the annual ADR of each hotel. This difference was then divided by the annual ADR of the competitive set and multiplied by 100 . The result of this calculation is the percentage difference in ADR from that of the competitive set. For example, if a specific hotel had an annual ADR of $\$ 50.00$, and the annual ADR of the competitive set was $\$ 60.00$, the percentage difference would be -16.7 per cent $([\$ 50.00-\$ 60.00 / \$ 60.00] \times 100)$. Finally, the relative price position over the 11-year period was computed by averaging the annual values across the 11-year period. A positive relative price position represented hotels that, on average, priced above their competitive set over the period.

Relative price fluctuation: Relative price fluctuation represents a measure of relative variability in ADR over time and was computed for each hotel in the sample as the standard deviation of the annual ADR percentage difference from the competitive set over the 11-year period. For any given hotel property, the greater the variability in relative ADR over the 11-year period the higher the price fluctuation score.

\section{$\underline{\text { Analysis }}$}

Multiple regressions were used to test the effects of relative price position, and fluctuation, on RevPAR performance. RevPAR was entered as the dependent variable in the analyses, with relative price position and relative price fluctuation entered as the independent variables.

Data analysis consisted of two stages. In Stage 1, we tested the general effects of relative price position and fluctuation on RevPAR performance using the data for all of the hotels in the sample. Given their expected effects on RevPAR performance, hotel type and location were entered as control variables in the analysis. The luxury hotel segment was used as the reference group for hotel type, with resort location used as the reference group for the location variable. Stage 2 was comprised of a segment analysis, where the effects of relative price position and fluctuation on RevPAR performance were examined by hotel type, while controlling for the potential effect of hotel location on RevPAR performance.

\section{Results}

Means, standard deviations and Pearson product-moment correlations for all of the variables are provided in Table 1. The mean RevPAR across the entire sample was $\$ 56.54$. The negative value of 1.49 for the mean relative price position indicates that, overall, there was a strong tendency towards a 
price position below the competitive set. In terms of relative price fluctuation, the overall mean value was 6.11 suggesting a fairly significant amount of relative price shifting by the hotels sampled. The Pearson product-moment correlations indicated little or no correlation between relative price position, relative price fluctuation and the other independent variables.

A detailed examination of the variables by hotel location and type shown in Table 2 provides additional insights into the pricing dynamics of the hotels sampled. Of the 6998 hotels sampled, the majority are economy (33.6 per cent; $n=2351)$. Upscale and budget hotels represent 27.5 per cent $(n=$ $1923)$ and 20.9 per cent $(n=1461)$ of the sample respectively, with midscale at 14.8 per cent $(n=1036)$ and luxury at 3.2 per cent $(n=227)$. In terms of location, the majority of hotels are in suburban locations (49.4 per cent; $n=3459)$, with urban next at 13.8 per cent $(n=968)$. Interstate and small town/metro locations have an approximately equal number of observations, at 10.7 per cent $(n=746)$ and 10.6 per cent $(n=743)$, respectively. Airport locations represent 9.1 per cent $(n=639)$ of the sample, with resorts at 6.3 per cent $(n=443)$.

As expected, RevPAR peaked in the luxury hotel segment with a mean of $\$ 137.66$, and was lowest in the budget segment (\$31.71). The mean relative price position was lower than the competition for hotels in the budget segment across the range of hotel locations, while mid-scale hotels' mean relative price position was lower than the competition in all hotel locations except interstates. Economy, upscale and luxury hotels, on average, had relative price positions above the competition regardless of hotel location, with the greatest degree of dispersion in airport and resort locations (see standard deviations in Table 2). In terms of relative price fluctuation, the mean values across hotel types are generally similar, although luxury hotels in resort, suburban and airport settings have higher price fluctuation. Upscale hotels tend to exhibit slightly more relative price stability (lower relative price fluctuation) than other hotel types. The summary statistics also reveal a range of values suggesting that hotels vary in their level of relative price consistency, particularly in suburban locations.

\section{$\underline{\text { Regression Models }}$}

The regression results for Stage 1 of the analysis are provided in Table 3. The overall model which includes relative price position, relative price fluctuation and hotel location and types was significant in explaining RevPAR performance $(F=779.13, P<0.001)$, with 55 per cent of the variation ( $R$ squared $=0.55$ ) in RevPAR accounted for by the model. As expected, the control variables, hotel type and location, were significant $(P<0.001)$, with RevPAR significantly higher for luxury hotels than for any other hotel type, and resort hotels, on the whole, yielding a significantly higher mean RevPAR than any 
other hotel location. Both relative price position and fluctuation were significant $(t=19.22, P<0.001$ and $t=-11.7, \mathrm{P}<0.001$ respectively), with the signs of the coefficients indicating a positive relationship between relative price position and RevPAR performance and a negative relative price fluctuationRevPAR relationship. The positive coefficient for price position suggests that price positioning higher than competitors is associated with stronger RevPAR performance over time. Furthermore, the negative coefficient for price fluctuation indicates that the greater the amount of price instability or shifting relative to the competitive set, the lower the RevPAR performance.

Given the significant relationships of relative price position and relative price fluctuation with RevPAR performance for the industry sample as a whole, we further analyzed the data by hotel type in Stage 2 of the analysis (see Table 4). The overall model by hotel type was significant (Budget: $F=18.77$, $P<0.001 ; R$-squared $=0.09$; Economy: $F=90.93, P<0.001 ; R$-squared $=0.21$; Midscale: $F=39.45$, $\mathrm{P}<0.001 ; \mathrm{R}$-squared $=0.21 ;$ Upscale: $\mathrm{F}=85.95, \mathrm{P}<0.001 ; \mathrm{R}$-squared $=0.24$; Luxury: $\mathrm{F}=5.66, \mathrm{P}<0.001 ; \mathrm{R}$ squared $=0.12$ ). The control variable, hotel location, was significant in all five regressions, supporting the significant relationship of location with RevPAR performance identified in Stage 1 of the analysis. For example, across all hotel types, RevPAR was lower for suburban and airport hotels, when compared with resort hotels.

The results indicate that the effects of relative price position were significant in each of the five regression models, with the signs of the coefficients indicating a positive relationship between relative price position and RevPAR performance. This supports the Stage 1 findings. Turning to relative price fluctuation, the values for the coefficients for relative price fluctuation across all hotel types indicate a negative relationship with RevPAR performance. In other words, the greater the degree of price fluctuation relative to the competitive set, the lower the RevPAR performance. Interestingly, the relationship of relative price fluctuation with RevPAR was only statistically significant for economy, midscale and upscale hotels ( $t--12.45, \mathrm{P}<0.001, t=-5.72, P<0.001$ and $t=-7.62, P<0.001$ respectively). While the coefficients were negative, relative price fluctuation was not statistically significant for budget and luxury hotels. 
Table 1: Summary sample statistics and Pearson correlation coefficients

\begin{tabular}{|c|c|c|c|c|c|c|c|c|c|c|c|c|c|c|c|c|}
\hline \multicolumn{17}{|c|}{ Pearson correlation coefficients } \\
\hline & Mean & $S T D$ & 1 & 2 & 3 & 4 & 5 & 6 & 7 & 8 & 9 & 10 & 11 & 12 & 13 & 14 \\
\hline 1. RevPAR & 56.54 & 33.06 & $1 *$ & $0.34 *$ & $-0.10^{\star}$ & $0.45^{\star}$ & $0.43^{\star}$ & $-0.09 \star$ & $-0.18^{\star}$ & $-0.38^{\star}$ & $0.32^{\star}$ & $-0.15^{\star}$ & $0.03 \star \star \star$ & $-0.18^{\star}$ & $-0.14^{\star}$ & $0.23 \star$ \\
\hline $\begin{array}{l}\text { 2. Price } \\
\text { position }\end{array}$ & -1.49 & 11.00 & - & 1 & $0.04 \star$ & $0.09^{\star}$ & $0.21 \star$ & $-0.03 \star \star$ & $0.17^{\star}$ & $-0.45^{\star}$ & 0.02 & $-0.04 *$ & $0.02 * \star * k$ & 0 & 0.01 & $0.04 *$ \\
\hline $\begin{array}{l}\text { 3. Price } \\
\text { fluctuation }\end{array}$ & 6.11 & 3.19 & - & - & 1 & $0.06^{\star}$ & $-0.11^{\star}$ & $0.04 *$ & 0.01 & $0.05 \star$ & $-0.04^{\star}$ & $0.03 * \star$ & 0.01 & -0.02 & $-0.04^{\star}$ & $0.06^{\star}$ \\
\hline 4. Luxury & 0.03 & 0.18 & - & - & - & 1 & $-0.11^{\star}$ & $-0.07^{\star}$ & $-0.13^{\star}$ & $-0.09 \star$ & $0.13^{\star}$ & $-0.08 *$ & $-0.04 \star$ & $-0.06^{\star}$ & $-0.06^{\star}$ & $0.18^{\star}$ \\
\hline 5. Upscale & 0.27 & 0.45 & - & - & - & - & 1 & $-0.25^{\star}$ & $-0.43^{\star}$ & $-0.31^{\star}$ & $0.21^{\star}$ & -0.02 & $0.10^{\star}$ & $-0.18^{\star}$ & $-0.16^{\star}$ & $0.06^{\star}$ \\
\hline 6. Midscale & 0.15 & 0.36 & - & - & - & - & - & 1 & $-0.29 k$ & $-0.21^{\star}$ & 0.01 & $-0.06^{\star}$ & $-0.02^{k \star k}$ & $0.03^{k \star}$ & $0.08^{\star}$ & -0.01 \\
\hline 7. Economy & 0.34 & 0.47 & - & - & - & - & - & - & 1 & $-0.36^{\star}$ & $-0.17^{\star}$ & $0.05^{\star}$ & $-0.02 k \star k$ & $0.09 k$ & $0.08^{\star}$ & $-0.07^{\star}$ \\
\hline 8. Budget & 0.21 & 0.41 & $1-$ & - & - & - & - & - & - & 1 & $-0.09^{\star}$ & $0.05^{\star}$ & $-0.04^{\star}$ & $0.08^{\star}$ & $0.02^{\star \star \star}$ & $-0.06^{\star}$ \\
\hline 9. Urban & 0.14 & 0.35 & - & - & - & - & - & - & - & - & 1 & $-0.39 \star$ & $-0.12^{\star}$ & $-0.13^{\star}$ & $-0.13^{\star}$ & $-0.10^{\star}$ \\
\hline 10. Suburban & 0.49 & 0.50 & - & - & - & - & - & - & - & - & - & 1 & $-0.31 *$ & $-0.34^{\star}$ & $-0.34^{\star}$ & $-0.25^{\star}$ \\
\hline 11. Airport & 0.09 & 0.29 & - & - & - & - & - & - & - & - & - & - & 1 & $-0.10^{\star}$ & $-0.10^{\star}$ & $-0.08^{\star}$ \\
\hline 12. Interstate & 0.11 & 0.31 & - & - & - & - & - & - & - & - & - & - & - & 1 & $-0.11^{\star}$ & $-0.08^{\star}$ \\
\hline $\begin{array}{l}\text { 13. Small } \\
\text { town/ } \\
\text { metro }\end{array}$ & 0.11 & 0.31 & - & - & - & - & - & - & - & - & - & - & - & - & 1 & $-0,08^{\star}$ \\
\hline 14. Resort & 0.06 & 0.24 & - & - & - & - & - & - & - & - & - & - & - & - & - & 1 \\
\hline
\end{tabular}

$\star P<0.001 ; \star \star x<0.01 ; \star \star \star P<0.05$

Table 2: Summary statistics by hotel type and location

\begin{tabular}{|c|c|c|c|c|c|c|c|c|c|c|c|c|c|c|}
\hline \multirow[t]{2}{*}{ Hotel location } & \multirow[t]{2}{*}{ Hotel type } & \multirow[t]{2}{*}{$N$} & \multicolumn{3}{|c|}{ Mean } & \multicolumn{3}{|c|}{$S T D$} & \multicolumn{3}{|c|}{ Min. } & \multicolumn{3}{|c|}{ Max. } \\
\hline & & & RevPAR & $\begin{array}{c}\text { Price } \\
\text { position }\end{array}$ & $\begin{array}{c}\text { Price } \\
\text { fluctuation }\end{array}$ & RevPAR & $\begin{array}{c}\text { Price } \\
\text { position }\end{array}$ & $\begin{array}{c}\text { Price } \\
\text { fluctuation }\end{array}$ & RevPAR & $\begin{array}{c}\text { Price } \\
\text { position }\end{array}$ & $\begin{array}{c}\text { Price } \\
\text { fluctuation }\end{array}$ & RevPAR & $\begin{array}{c}\text { Price } \\
\text { position }\end{array}$ & $\begin{array}{c}\text { Price } \\
\text { fluctuation }\end{array}$ \\
\hline \multirow[t]{5}{*}{ Urban } & Budget & 109 & 38.69 & -9.94 & 6.63 & 16.00 & 12.51 & 3.34 & 17.77 & -45.98 & 1.46 & 99.80 & 30.83 & 16.39 \\
\hline & Economy & 129 & 59.05 & 1.74 & 5.95 & 23.20 & 8.94 & 2.85 & 28.14 & -30.55 & 1.92 & 170.48 & 18.92 & 17.79 \\
\hline & Midscale & 147 & 63.29 & -3.64 & 6.15 & 27.82 & 9.13 & 2.74 & 21.27 & -27.97 & 1.90 & 162.14 & 37.68 & 14.80 \\
\hline & Upscale & 495 & 95.03 & 0.32 & 5.22 & 40.15 & 8.74 & 2.74 & 26.58 & -29.20 & 1.23 & 289.88 & 31.63 & 19.50 \\
\hline & Luxury & 88 & 144.16 & 3.73 & 6.32 & 82.08 & 11.97 & 3.87 & 55.87 & -18.12 & 1.74 & 508.54 & 55.36 & 28.28 \\
\hline \multirow[t]{5}{*}{ Suburban } & Budget & 798 & 31.26 & -12.36 & 6.67 & 8.91 & 10.62 & 3.45 & 13.35 & -42.72 & 1.15 & 76.78 & 30.85 & 34.78 \\
\hline & Economy & 1260 & 48.18 & 0.97 & 6.27 & 13.32 & 8.78 & 3.13 & 13.28 & -38.36 & 1.26 & 129.44 & 34.66 & 23.27 \\
\hline & Midscale & 430 & 48.27 & -3.12 & 6.67 & 16.16 & 8.77 & 3.26 & 17.81 & -33.42 & 1.22 & 138.78 & 26.17 & 29.66 \\
\hline & Upscale & 909 & 70.60 & 3.05 & 5.52 & 19.70 & 8.81 & 2.67 & 31.91 & -21.48 & 0.83 & 160.00 & 33.44 & 19.98 \\
\hline & Luxury & 62 & 121.26 & 3.81 & 7.06 & 55.75 & 12.21 & 4.61 & 51.85 & -22.36 & 1.51 & 276.10 & 34.69 & 29.92 \\
\hline \multirow[t]{5}{*}{ Airport } & Budget & 95 & 34.53 & -9.55 & 6.53 & 11.54 & 10.24 & 3.18 & 16.11 & -36.56 & 2.13 & 68.35 & 21.16 & 15.08 \\
\hline & Economy & 187 & 51.99 & 0.54 & 7.02 & 14.43 & 9.23 & 3.66 & 24.14 & -27.25 & 1.42 & 90.99 & 23.03 & 23.84 \\
\hline & Midscale & 77 & 51.18 & -4.86 & 6.69 & 15.71 & 8.30 & 2.75 & 25.04 & -22.98 & 1.54 & 97.34 & 25.57 & 14.51 \\
\hline & Upscale & 274 & 74.82 & 2.77 & 5.41 & 19.95 & 10.91 & 2.53 & 36.13 & -27.63 & 1.50 & 140.21 & 34.49 & 17.69 \\
\hline & Luxury & 6 & 85.07 & 2.42 & 7.08 & 14.45 & 15.94 & 4.10 & 66.51 & -14.38 & 3.69 & 106.62 & 32.66 & 14.87 \\
\hline \multirow[t]{4}{*}{ Interstate } & Budget & 232 & 28.67 & -9.60 & 5.83 & 7.15 & 11.60 & 2.90 & 13.34 & -34.24 & 1.78 & 53.69 & 25.17 & 19.33 \\
\hline & Economy & 352 & 44.11 & 2.25 & 5.84 & 9.99 & 9.34 & 3.46 & 20.98 & -28.81 & 0.81 & 72.13 & 31.72 & 36.20 \\
\hline & Midscale & 140 & 38.78 & 0.17 & 6.36 & 9.07 & 7.96 & 3.18 & 20.67 & -20.30 & 1.22 & 71.24 & 18.79 & 17.30 \\
\hline & Upscale & 22 & 55.19 & 4.72 & 5.11 & 10.44 & 8.11 & 1.72 & 34.27 & -13.73 & 2.64 & 77.91 & 19.03 & 8.78 \\
\hline \multirow[t]{5}{*}{ Resort } & Budget & 48 & 36.41 & -9.47 & 6.82 & 15.36 & 10.40 & 3.60 & 16.01 & -31.42 & 2.10 & 89.92 & 16.90 & 19.03 \\
\hline & Economy & 86 & 53.51 & 0.17 & 6.06 & 18.28 & 9.57 & 2.80 & 28.23 & -22.76 & 2.06 & 134.07 & 38.12 & 16.75 \\
\hline & Midscale & 64 & 59.74 & -2.38 & 7.55 & 21.08 & 10.63 & 4.57 & 23.40 & -31.65 & 1.53 & 119.14 & 32.47 & 25.01 \\
\hline & Upscale & 174 & 99.61 & 2.03 & 6.63 & 39.16 & 11.77 & 3.79 & 35.50 & -23.70 & 1.93 & 241.06 & 74.77 & 23.12 \\
\hline & Luxury & 71 & 148.38 & 5.11 & 8.40 & 71.99 & 15.11 & 5.12 & 52.72 & -28.72 & 2.50 & 427.91 & 49.20 & 32.48 \\
\hline \multirow{4}{*}{$\begin{array}{l}\text { Small town/ } \\
\text { metro }\end{array}$} & Budget & 179 & 30.66 & -9.89 & 6.14 & 9.23 & 10.91 & 3.12 & 16.37 & -37.61 & 1.29 & 64.51 & 23.18 & 27.68 \\
\hline & Economy & 337 & 45.64 & 1.95 & 5.48 & 10.09 & 8.17 & 2.60 & 22.23 & -25.36 & 1.50 & 78.08 & 31.79 & 18.74 \\
\hline & Midscale & 178 & 44.33 & -0.94 & 5.72 & 14.47 & 8.61 & 2.93 & 21.89 & -29.99 & 1.59 & 118.37 & 18.79 & 25.20 \\
\hline & Upscale & 49 & 63.36 & 6.83 & 5.41 & 19.17 & 9.67 & 2.75 & 32.92 & -16.05 & 1.48 & 111.95 & 26.60 & 14.91 \\
\hline
\end{tabular}


Table 3: Effects of price position and fluctuation on RevPAR performance

\begin{tabular}{|c|c|c|}
\hline \multirow[t]{2}{*}{ Independent variables } & \multicolumn{2}{|c|}{$\begin{array}{c}\text { Dependent variable: RevPAR } \\
\text { performance }\end{array}$} \\
\hline & Coefficient & t-value \\
\hline \multicolumn{3}{|l|}{ Hotel location $^{2}$} \\
\hline Urban & -0.45 & -0.35 \\
\hline Suburban & -18.58 & $-16.15^{\star}$ \\
\hline Airport & -15.61 & $-11.21^{\star}$ \\
\hline Interstate & -24.15 & $-17.40^{\star}$ \\
\hline Small town/metro & -22.03 & $-15.91^{\star}$ \\
\hline \multicolumn{3}{|l|}{ Hotel type $e^{\mathrm{b}}$} \\
\hline Upscale & -52.30 & $-32.90^{\star}$ \\
\hline Midscale & -75.19 & $-44.61 \star$ \\
\hline Economy & -76.55 & $-47.48^{\star}$ \\
\hline Budget & -86.47 & $-50.76^{\star}$ \\
\hline Price position & 0.53 & $19.22^{\star}$ \\
\hline Price fluctuation & -0.99 & $-11.7 \star$ \\
\hline $\mathrm{F}$ & \multicolumn{2}{|c|}{$779.13^{\star}$} \\
\hline$R^{2}$ & \multicolumn{2}{|c|}{0.55} \\
\hline
\end{tabular}

${ }^{2}$ Resort location was used as the reference group in the regression. b.The luxury hotel category was used as the reference group in the regression.

$\star P<0.001$.

Table 4: Effects of price position and fluctuation on RevPAR performance by hotel type

\begin{tabular}{|c|c|c|c|c|c|c|c|c|c|c|}
\hline \multirow[t]{3}{*}{ Independent wariables } & \multicolumn{10}{|c|}{ Dependent mariable: RevPAR Pefformance } \\
\hline & \multicolumn{2}{|c|}{ Budget } & \multicolumn{2}{|c|}{ Eosnowy } & \multicolumn{2}{|c|}{ Midecale } & \multicolumn{2}{|c|}{ Upscale } & \multicolumn{2}{|c|}{ Lesoury } \\
\hline & Coefficient & t-value & Coefficient & t-value & Cosfficient & $t$-wabue & Coefficient & t-palive & Coefficient & t-value \\
\hline \multicolumn{11}{|l|}{ Hotel location ${ }^{2}$} \\
\hline Urban & 2.31 & 1.37 & 4.59 & $2.67 \star \star \star$ & 2.79 & 1.09 & -5.71 & $-2.38 \star \star \star \star$ & -4.52 & -0.40 \\
\hline Suburban & -4.78 & $-3.29 \star \star$ & -5.53 & $-4.01 *$ & -11.96 & $-5.24 *$ & -31.64 & $-14.07 \star$ & -26.69 & $-2,21 \star \star \star \star$ \\
\hline Airport & -1.90 & -1.10 & -0.73 & $-0,46$ & -8.22 & $-2.86 \star \star$ & -27.40 & $-10.41^{\star}$ & -60.72 & $-2.07^{\star \star \star *}$ \\
\hline Interstate & -7.85 & $-5.06 \star$ & -10.71 & $-7.19 \star$ & -23.29 & $-9.04^{\star}$ & -48.96 & $-8.00 \star$ & - & - \\
\hline Small town/metro & -5.78 & $-3.64^{\star}$ & -9.40 & $-6.28 *$ & -17.84 & $-7.14 *$ & -41.85 & $-9.54 *$ & - & - \\
\hline Price position & 0.13 & $5.51^{\star}$ & 0.52 & $18.27^{\star}$ & 0.46 & $7.68^{\star}$ & 0.73 & $11.21 \star$ & 1.53 & $4.32^{\star}$ \\
\hline Price fluctuation & -0.12 & -1.56 & -1.02 & $-12.45^{\star}$ & -0.96 & $-5.72^{\star}$ & -1.69 & $-7.62 \star$ & -1.16 & -1.12 \\
\hline $\mathrm{F}$ & \multicolumn{2}{|c|}{$18.77^{\star}$} & \multicolumn{2}{|c|}{$90.93^{\star}$} & \multicolumn{2}{|c|}{$39.45^{\star}$} & \multicolumn{2}{|c|}{$85.95^{\star}$} & \multicolumn{2}{|c|}{$5.66 \star^{\star 1.12}$} \\
\hline$R^{2}$ & \multicolumn{2}{|c|}{0.09} & \multicolumn{2}{|c|}{0.21} & \multicolumn{2}{|c|}{0.21} & \multicolumn{2}{|c|}{0.24} & \multicolumn{2}{|c|}{0.12} \\
\hline
\end{tabular}

'Resort location was used as the reference group in the regressions.

$* P<0.001 ; * * P<0.01 ; * * * P<0.05$. 


\section{Discussion}

This study extends the literature in the domain of strategic price positioning by examining, in the context of the hotel industry, the joint effects of relative price position, and fluctuation, on revenue performance over time. While prior work has examined the performance effects of price positioning in this context (for example, Chung, 2000; Enz et al, 2009), the simultaneous impact of both relative price position, and fluctuation, has not been considered.

The results of the current study indicate a significant relationship between both dimensions of strategic pricing and revenue. Given the positive coefficient for relative price positioning, it could be argued that, regardless of hotel type (that is, luxury through budget), a price position above that of the competitive set yields the highest revenue results. Similarly, it could be suggested that, given the negative coefficient for relative price fluctuation, the greater the amount of relative price instability or shifting relative to the competitive set, the lower the RevPAR performance. However, the possibility of reverse causation cannot be ignored. A viable alternative interpretation of the results might be that poor performers (as measured by RevPAR) are more likely to experiment with relative price positioning, and are, therefore, more prone to relative price fluctuation than strong performers. In other words, could it be that RevPAR shapes relative position and relative fluctuation, and not the reverse?

To investigate this possibility, we conducted additional analyses to determine if the results obtained in the main study held for hotels whose performance improved over the 11-year time period. First, using RevPAR growth over the 11-year period (that is, growth in RevPAR from the first, to the last, year of the period), we isolated those hotels with positive values and ran the same regression analysis as in the main study. Second, using average annual RevPAR growth (that is, average of the RevPAR growth for each of the 11 years), we again isolated those hotels with positive values and re-ran the regression analysis. In both analyses, the results of the main study were replicated: a positive relationship of relative price positioning with RevPAR, and a negative relative price fluctuation-RevPAR relationship (Relative price position: $\beta=0.56, P<0.0001$ (RevPAR growth over the 11-year period), $\beta=0.57, P<$ 0.0001 (average annual RevPAR growth); Relative price fluctuation: $\beta=-1.21, P<0.0001$ (RevPAR growth over the 11-year period), $\beta=-1.15, P<0.0001$ (average annual RevPAR growth). ${ }^{5}$ Together these results strengthen the argument that that RevPAR performance will be strongest for hotels that price higher than the competition and maintain a consistent relative price position.

The study's findings also indicate that, while the negative impact of relative price fluctuation on revenue performance held across all hotel types, it was statistically significant for economy, midscale 
and upscale hotels only. In a follow-up analysis we examined the standard deviation of demand across hotel segments (measured as the standard deviation in mean occupancy percentage), to assess the potential for differences in competitive intensity across segments to explain this finding. However, we found that range in the dispersion in occupancy levels across the five segments was relatively small (budget: 15.47 per cent; economy: 11.98 per cent; midscale: 14.5 per cent; upscale: 11.5 per cent; luxury: 11.6 per cent), suggesting that variations in competitive intensity may not be driving the differential effect of relative price fluctuation on revenue performance across segments. An alternative potential explanation for our finding is that it may be a function of more regular, and by extension, predictable, promotional activity in these segments than in the budget or luxury segments. Budget and luxury hotels hold more clearly defined strategic positions (that is, low cost and differentiation respectively) than economy, midscale or upscale hotels. Thus, economy, midscale and upscale segments are more prone to cross segment competitive pricing, and may shift their relative prices more regularly than economy or luxury hotels in response to the broader market as opposed to their competitive set alone. While more irregular promotion patterns may dampen consumers' tendencies to postpone purchases to obtain better deals (Krishna, 1994), more regular and predictable promotional activity may train consumers to wait for deals. In other words, a higher incidence of promotional activity might cause consumers to 'hold out' for lower rates, leading to lower revenue gains. This behavior fits with the notion of the strategic customer proposed by Anderson and Wilson (2003). They suggest that, if a consumer understands the pricing strategy of a given firm, segment or industry, and has access to demand information, he may decide to defer purchase on the belief that a cheaper offering may yet become available - a practice that they demonstrate to result in significantly reduced revenues where standard RM approaches to pricing are applied.

Other factors may also play a role in the nature of the relative price fluctuation- RevPAR relationship. For example, the ability of properties in the luxury segment to make greater, non-price distinctions between differentially priced product offerings may also temper the relative price fluctuation-RevPAR relationship. In other words, a broader range of product/service offerings at the individual property level affords the opportunity to legitimize greater relative price fluctuation.

This study's findings should serve to guide revenue managers and other decision makers as they strive to effectively position themselves against their competition. The goal is not to inform tactical pricing decisions but rather yield insights into the types of strategic positioning goals those tactical pricing decisions should support. Given the diminished likelihood of reverse causality, as indicated by the follow-up analyses to the main study, our results suggest that minimizing relative price fluctuation, 
as well as pricing above the competitive set, may be two long-term strategies for enhancing revenue flows. However, their pursuit may not yield the desired revenue gains if limiting factors such as weak brand reputation, and poor product/ service quality vis a vis the competitive set, are present. For example, there is little chance of sustaining a price position above that of the competition if the service facility and operations team are unable to support the delivery of a superior customer experience. Thus, an initial evaluation of the firm's strengths and weaknesses relative to the competition is a first step in assessing the viability of adopting these long-term revenue enhancement strategies.

Assuming adoption is viable, the focus must be on managing the inherent short-term fluctuation in relative pricing for RM to support an overall strategic positioning goal of a relatively stable price position above that of the competition. Maintaining an average price position above that of the competitive set may not necessarily translate into positioning above the competition across all customer segments and distribution channels, rather it is a function of how the firm balances sales volume and price across each individual segment and channel. The intelligent application of discounts is essential to effectively achieving this balance. When trying to offload distressed inventory, firms need to avoid offering deep discounts to customer segments that would otherwise be willing to pay a higher rate. This can be achieved by, for example, limiting availability of those discounts to price conscious customers via opaque distribution channels. Rather than rely solely on discounts during low demand periods, revenue managers should also tap into their existing customer bases to target high-value customers with premium-priced, upgraded package offerings.

In terms of relative price fluctuation, the study's findings suggest that maintaining a stable relative price position is most important for midscale, upscale and economy hotels. While we found that the degree of variability in relative price positioning over time was negatively related to RevPAR performance for budget and luxury hotels, the insignificance of this relationship suggests that maintaining relative price stability may be less crucial for hotels in these sectors.

\section{Conclusion}

Developments in the domain of price optimization are driving tactical pricing decisions that explicitly consider the impact of competitor pricing actions on short-term revenue performance. While these developments represent an important milestone in the evolution of RM, it is important that the long-term performance implications of price positioning relative to the competition are understood. To our knowledge, this study is one of the first to consider the revenue implications of two dimensions of strategic price positioning, relative price position and relative fluctuation, in the RM environment. While 
it provides insights into the important role that price positioning plays in revenue performance, there are a number of opportunities for research in this domain. As this study was conducted in the context of the hotel industry, a similar analysis across other RM-oriented industries (for example, airline, car rental) is warranted to assess the generalizability of this study's findings to other environments. Second, the potential role of price predictability in the price fluctuation-revenue performance relationship merits further examination. If consumers perceive that the promotional activity of a given firm is predictable, they may act as strategic consumers as suggested by Anderson and Wilson (2003) and hold out for cheaper prices, yielding a negative impact on revenue performance. Thus, it behooves revenue managers to understand how the regularity of promotional activity impacts consumer behavior and leverage that knowledge in tactical pricing decisions. Third, the categorical classification of the STR data used in this study precluded examination of hotel properties on the margins (for example, boundaries of suburban/urban, midscale/up-scale). Future research could explore the dynamics of performance for those types of properties. Fourth, while this study crossed periods of both economic prosperity and downturn, further research isolating performance under specific economic conditions is merited. Finally, while this study isolated the effects of two components of strategic price positioning on revenue performance, future research should investigate how these variables interact with other determinants of revenue performance.

\section{References}

Aaker, D. (1996) Building Strong Brands. New York: The Free Press.

Ailawadi, K., Lehmann, D. and Neslin, S. (2001) Market response to a major policy change in the marketing mix: Learning from Procter \& Gamble's value pricing strategy. Journal of Marketing 65(1): 44-61.

Alam, I.S. and Sickles, R.C. (2000) Time series analysis of deregulatory dynamics and technical efficiency: The case of the U.S. airline industry. International Economic Review 41(1): 203-218.

Alam, Ross, L.B. and Sickles, R.B. (2001) Time series analysis of strategic behavior in the U.S. airline industry. Journal of Productivity Analysis 16(1): 49-62.

Anderson, C.K. and Wilson, J.G. (2003) Wait or buy? The strategic consumer: Pricing and profit implications. Journal of the Operational Research Society 54(3): 299-306.

Bolton, R. and Shankar, V. (2003) An empirically derived taxonomy of retailer pricing and promotion strategies. Journal of Retailing 79(4): 213-224. 
Chung, K. (2000) Hotel room rate pricing strategy for market share in oligopolistic competition - Eightyear longitudinal study of super deluxe hotels in Seoul. Tourism Management 21(2): 135-145.

Cross, R., Higbie, J. and Cross, D. (2009) Revenue management's renaissance. Cornell Hospitality Quarterly 50(1): 56-81.

Enz, C.A. and Canina, L. (2010) Competitive pricing in European hotels. In: J.S. Chen (ed.) Advances in Hospitality and Leisure (6), Emerald Group Publishing, pp. 3-25.

Enz, C., Canina, L. and Lomanno, M. (2004) Why discounting doesn't work: The dynamics of rising occupancy and falling revenue among competitors. Center for Hospitality Research Report 4(7): 6-25.

Enz, C., Canina, L. and Lomanno, M. (2009) Competitive pricing decisions in uncertain times. Cornell Hospitality Quarterly 50(3): 325-341.

Erdem, T. and Swait, J. (1998) Brand equity as a signaling phenomenon. Journal of Consumer Psychology $7(2): 131-157$.

Gallego, G. and Hu, M. (2007) Dynamic Pricing of Perishable Assets under Competition. New York: USA, Columbia University Working Paper.

Hanssens, D. (1980) Market response, competitive behavior, and time series analysis. Journal of Marketing Research 17(4): 470-485.

Hawtin, M. (2003) The practicalities and benefits of applying revenue management to grocery retailing, and the need for effective business rule management. Journal of Revenue and Pricing Management 2(1): 61-68.

Krishna, A. (1994) The impact of dealing patterns on purchase behavior. Marketing Science 13(4): 351373.

Lambin, J., Naert, P. and Bultez, A. (1975) Optimal marketing behavior in oligopoly. European Economic Review 6(2): 105-128.

Levin, Y., McGill, J. and Nediak, M. (2009) Dynamic pricing in the presence of strategic consumers and oligopolistic competition. Management Science 55(1): 32-46.

Lieberman, W. (2004) Revenue management trends and opportunities. Journal of Revenue and Pricing Management 3(1): 91-99.

Mela, C., Gupta, S. and Lehmann, D. (1997) The long-term impact of promotion and advertising on consumer brand choice. Journal of Marketing Research 34(2): 248-261. 
Mookherjee, R. and Friesz, T. (2008) Pricing, allocation, and overbooking in dynamic service network competition when demand is uncertain. Production and Operations Management 17(4): 455474.

Perakis, G. and Sood, A. (2006) Competitive multi-period pricing for perishable products: A robust optimization approach. Mathematical Programming 107(1): 295-335.

Shankar, V and Bolton, R. (2004) An empirical analysis of determinants of retailer pricing strategy. Marketing Science 23(1): 28-49.

Swait, J. and Erdem, T. (2002) The effects of temporal consistency of sales promotions and availability on consumer choice behavior. Journal of Marketing Research 39(3): 304-320.

Talluri, K. and Van Ryzin, G. (2004) The Theory and Practice of Revenue Management. New York: Springer.

Thaler, R. (1985) Mental accounting and consumer choice. Marketing Science 4(3): 199-214.

\footnotetext{
${ }^{1}$ Rather than examine technical efficiency in terms of physical inputs and outputs as in previous studies (for example, Alam and Sickles, 2000), Alam et al (2001) looked at oligopolistic pricing behavior as measured by means and distributions of sustained non-marginal cost pricing policies.

${ }^{2}$ Transaction utility is the perceived value associated with getting a good deal.

${ }^{3}$ STR's location segments are defined as follows: Urban: A densely populated area in a large metropolitan area (for example, Adanta, Boston); Suburban: Suburbs of metropolitan markets (for example, Sags Harbor and White Plains, New York, near New York City); Airport: Hotels in close proximity of an airport that primarily serve demand from airport traffic; Interstate/motorway: Hotels in close proximity of major highways, motorways or other major roads whose primary source of business is through passerby travel; Resort: Any hotel located in a resort area or market where a significant source of business is derived from leisure/destination travel (for example, Orlando, Lake Tahoe, Daytona Beach); Small Metro/Town: Areas with either smaller population or limited services, in remote locations, populated with less than 150000 people.

${ }^{4}$ STR defines five categories within metro markets - Luxury: top 15 per cent average room rates; Upscale: next 15 per cent average room rates; Midscale: middle 30 per cent average room rates; Economy: next 20 per cent average room rates; Budget: lowest 20 per cent average room rates. In rural or non-metro STR markets, the luxury and upscale segments are collapsed into a single upscale segment to form four price segment categories - Upscale: top 30 per cent average room rates; Midscale: next 30 per cent average room rates; Economy: next 20 per cent average room rates; Budget: lowest 20 per cent average room rates.

${ }^{5}$ Additional analysis can be obtained by contacting the authors.
} 